\title{
Efforts to Train the Character of Students by Using the Cooperative Learning Model Type GI (Group Investigation) in Science Learning
}

\section{${ }^{1}$ Agus Santoso}

Department of Science Education, Faculty of Teacher Training and Education, Lamongan Islamic University. Jl. Veteran No.53A Lamongan.

Email:_Agus_santoso@unisla.ac.id

\section{Article History}

Received:

Revised:

Published:

\begin{abstract}
Education up to now is considered as a medium to build knowledge as well as the personality of children to become better human beings, so positive learning must be instilled in learning. Planting characters can be realized through cooperative learning type group investigation. This research is to overcome learning problems in class related to the character of social care, environmental care, responsibility, and cooperation. This research was conducted in two cycles, using a characteristic behavior observation sheet instrument. Descriptive data analysis by looking at the increase in the percentage of character behavior in students. The implementation of learning in the first cycle is $94 \%$ and the second cycle is $100 \%$. Based on the results of observations in the first and second cycles there are positive character developments in students heading in a better direction than before. To build a positive character of character training students need to be carried out continuously so that their development is increasing and entrenched.
\end{abstract}

Keywords: Character, cooperative learning, group investigation

How to cite: Santoso, Agus. (2019). Efforts to Train the Character of Students by Using the Cooperative Learning Model Type GI (Group Investigation) in Science Learning. Science Education and Application Journal (SEAJ). Vol. 1 No.1: 25-33.

\section{INTRODUCTION}

Education has been regarded as an effective means of building children's personality and knowledge to be better. Muhaimin (2011) said that in order to obtain student graduates as expected, the education process must be evaluated and improved, such as the change of curriculum. One effort to improve the quality of education is to include character education in the curriculum in Indonesia.

In Indonesia the need for character education nowadays can be said to be very necessary and urgent. This is because there are currently many school children who are knowledgeable but whose personality is still lacking. Many circulated from several newspapers the more widespread students who opposed and were brave towards the teacher and had no manners. Samani (2011: 2) says that character education in Indonesia is very necessary to be developed, given the increasing juvenile delinquency, such as brawls, extortion / violence (bullying), senior domination of juniors, etc. which mostly occur in urban areas. Even the difficulty of building honest character in children. This is evidenced by the failure of the honesty canteen business in schools, because some students have not been honest.

So far, education is considered as an effort to build and produce intellectual and personality graduates to become better human beings. However, if education is only 
concerned with intellectual abilities without building character on students. The result is a violation of values and moral damage that will occur in society. In the end, this kind of education can be likened to a robot, which is having sense but not having a personality, empty of soul. The thing that becomes a problem again in the world of education is that there are many children who have knowledge of intelligence and intelligence, but their behavior does not reflect a noble person (Muhaimin, 2011: 10). According to the teacher's observations in the field, some students already have a fairly good intellectual level, but the students' intellectual development still needs to be balanced with the development of positive character in students.

Based on the results of observations in the class that are used as research, the characters that cause problems in classroom learning activities related to the character of social care, environmental care, responsibility, and cooperation. Therefore, efforts are needed to train these characters as the responsibility of teachers in the world of education, namely to produce children who have intellectual abilities and intact personalities with character. From previous research, there is a study of Abdullah, et al. 2015, which examines character-based education in the field of education, especially in schools.

One of the integrated science subject matter in SMP is pesticides, where in the material there are various disciplines contained in it, and suitable for use in cooperative learning models, which emphasize the existence of cooperation and build a sense of social. In pesticide materials, scientific disciplines can be found in the fields of biology, chemistry and physics. In the material it contains the use of pesticides and their impact on society and the natural environment. It is expected that students after learning activities can be more concerned with the environment, social care, and responsible.

The formation of character in schools in learning activities according to Najib (2010: 15) can be done as follows: instilling good values in children (knowing the good), motivating students to make children have reasons or desires to do good (desiring the good), build attitudes to love the good, to do good deeds (acting the good). Character education can be implemented in teaching and learning activities in the classroom through several lessons based on a philosophy that education is an effort to develop students' personalities as a whole (Akbar, S. et al. 2015: 27). Development of character education such as caring, cooperation, responsibility, etc. The following are the characters who will be trained:

1. Concern is a sense of empathy or the ability to understand, understand each other, and feel the feelings of others by expressing both verbally and behavior towards others. A caring attitude is a behavior or action that always wants to provide assistance or help to other people and communities in need. Concern for the environment is a behavior that pays attention to and preserves the environment.

2. Cooperation is the ability to solve problems by establishing cooperation and mutual cooperation attitude, this can be done with friends and other people (Muhaimin, 2011: 43). Working together is a character that must be developed in children so that students can achieve success, both in school and in society.

3. Responsibility is the feeling to bear the consequences of what is caused by his actions. With this character, students will be more careful in doing things.

Cooperative learning model is a learning that emphasizes the existence of cooperation, namely cooperation between students in learning activities through groups. In this learning students are divided into several groups to complete the tasks given by the teacher. The students are divided into several small groups then given direction to the material and tasks 
that have been determined. The purpose of cooperative learning is to build interactions between group members when working on tasks through group discussion activities. The learning activities are student centered.

Based on the opinions of a number of experts, the cooperative learning model is the model that is considered the most effective for the implementation of character education. In its implementation, some character values can be developed in it. These values such as independence, cooperation, openness, tolerance, respect for other people's opinions, being polite, courageous to think, creative, and dynamic (Muchlas, 2011: 159). According to Muchlas, any lesson if implementing this cooperative chase can be said to have implemented character education. However, the selection of learning materials related to character development in students will further enhance the effect of their effectiveness in implementing character education.

One type of cooperative learning is group investigation. In this learning involves students since planning, both in determining topics or material and ways to learn in the form of investigation. This learning model invites students to develop the ability to communicate both in communicating individually and in group process skills. Cooperative learning type group investigation models can train students to foster independent thinking skills and socializing skills. Active involvement of students can be seen starting from the initial learning activities to the final activities of learning (Nur, 2011: 63).

Based on the explanation from the background, the researcher tried to train the character through cooperative learning models type group investigation on science learning the theme of pesticides. This study aims to describe the implementation of learning and describe the results of student character training. Through this research, it is expected to be able to train and shape positive character in students.

\section{RESEARCH METHOD}

This research is included in the type of action research, because it is done to overcome the problems of classroom learning activities. The objectives of class action research in this study were students of class VIII-J in SMP Negeri 2 Kediri with a total of 38 students consisting of 4 male students and 34 female students, in the odd semester. This research was conducted in two rounds, namely the first round and the second round. The second round is a follow-up of the first round that is obtained from the results of teacher observation of student character and student responses. In the first round, it was carried out by conducting integrated science learning using the cooperative type group investigation model and training character values in students, while the teacher gave an assessment to students in the form of an observation sheet.

In the second round, it was carried out by carrying out integrated science learning in the cooperative model of group investigation type and exercising more character values in students in each learning activity if the trained character had not been seen in the first cycle, and related characters can be obtained from the material and learning model. The teacher gives an assessment to students in the form of an observation sheet. After that the students are given an evaluation sheet as a test and also given a student response questionnaire after the learning is complete. 


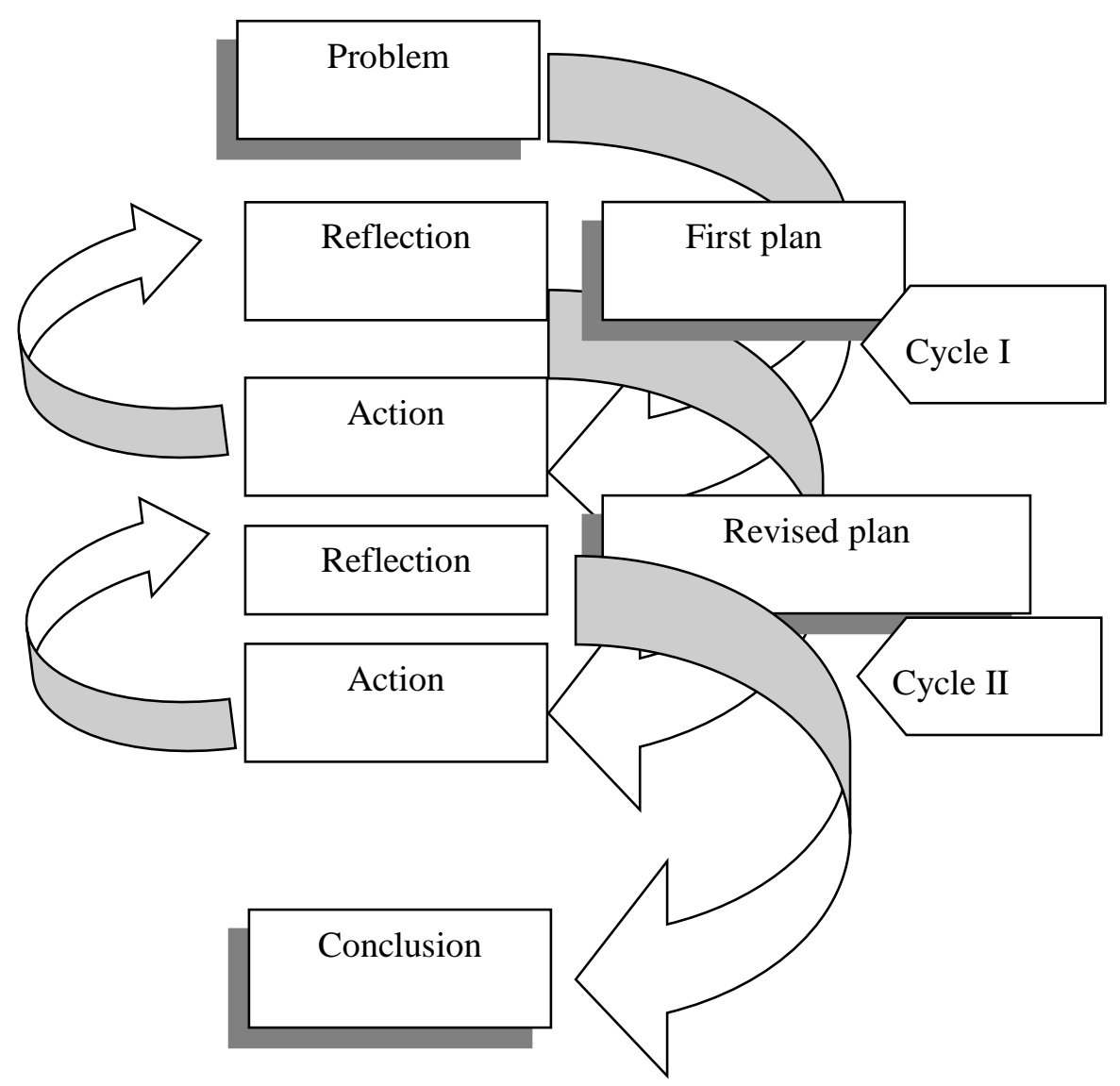

Figure 1. Design of classroom action research

To obtain data in this study, data collection methods were carried out by means of: tests and observation sheets. Tests are given to each student to get an idea of the value and completeness of student learning outcomes after learning activities. Observation or observation is used as an assessment instrument to measure individual behavior as well as in groups in an activity carried out. In this case what is observed is the activity of teachers and students during the teaching and learning process using cooperative learning models type group investigation. This observation sheet is also used to determine the assessment of character behavior in students. Data analysis was performed from the results of student learning outcomes tests and observations of character traits. Analysis of the results of student character development is used to determine the development of the character of students in the first cycle and in the second cycle, which is calculated using the formula:

$$
\mathrm{P}=\frac{\text { Number of score aspects of characters counted }}{\text { Total score for aspects of maximum total characters }} \times 100
$$

(Adapted from Riduwan, 2010)

This calculation is used to see the character development in each cycle.

\section{RESULTS AND DISCUSSION RESULT}

The results of this study are presented in descriptive form where the researcher describes the results of student learning, the feasibility of learning, the development of student character and student responses to learning activities. The results of student evaluations carried out in cycle 2 (final cycle) can be seen that there are 1 student who did not 
complete with a value of 72 , while the others completed above the KKM. Based on the results of the implementation of learning can be known in the first cycle (cycle I) when delivering experimental experiment procedures in detail have not been implemented by the teacher because the teacher is directly focused on guiding students to plan experiments in groups, and also because of haste because the time allocated is limited. In the second cycle there was a reflection and improvement of the learning activities that the teacher had carried out on cycle I.

Table 1. Results of learning implementation

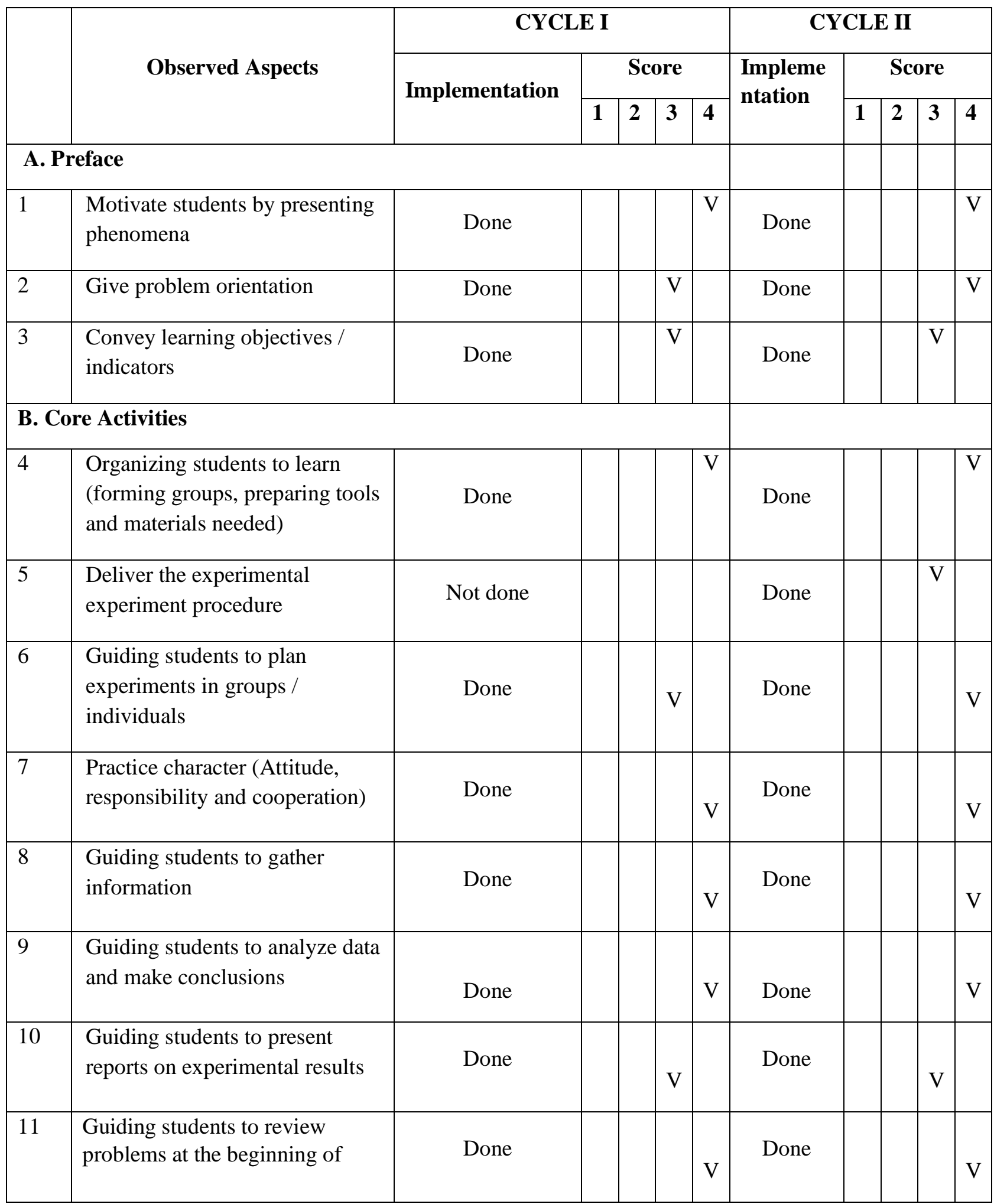




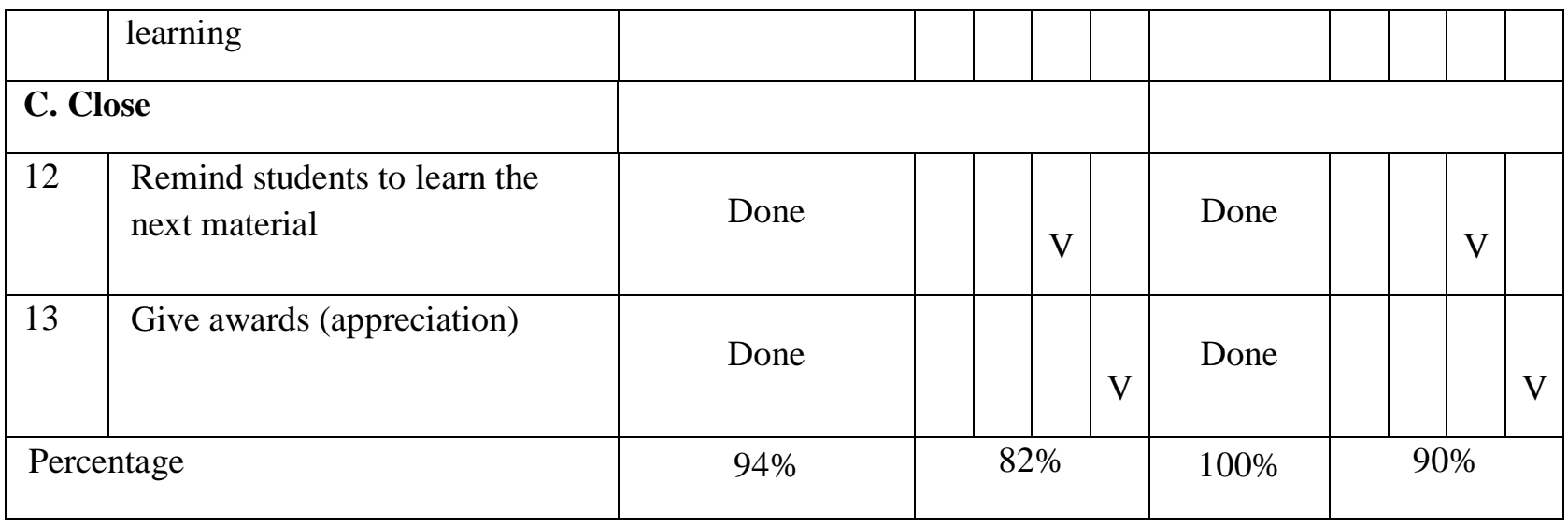

Based on the data in Table 1 it can be said that the teacher had managed science learning quite well. In each step the learning activities get an assessment of 3-4 so that it can be said that the teacher has done a good management of learning. The results of observations of student activities carried out during the learning activities take place by one observer. Student activities that are observed in a classical manner are affective students in the form of a character of social caring, environmental care, responsibility and cooperation.

Table 2. Results of analysis of social care attitudes

\begin{tabular}{|c|l|c|c|}
\hline Num & Aspects observed & Cycle I & Cycle II \\
\hline 1 & $\begin{array}{l}\text { Students are actively } \\
\text { involved during } \\
\text { learning activities }\end{array}$ & $64 \%$ & $88 \%$ \\
\hline 2 & $\begin{array}{l}\text { Students treat their } \\
\text { friends well }\end{array}$ & $84 \%$ & $76 \%$ \\
\hline 3 & $\begin{array}{l}\text { Helping friends in } \\
\text { conducting } \\
\text { experiments }\end{array}$ & $68 \%$ & $68 \%$ \\
\hline 4 & $\begin{array}{l}\text { Students behave and } \\
\text { say politely to teachers } \\
\text { and friends }\end{array}$ & $68 \%$ & $84 \%$ \\
\hline
\end{tabular}

Based on Table 2. it can be seen that the activities of students in socially caring characters in the first cycle experienced a better development in cycle II. It can be seen that more students carry out social caring activities based on indicators of social care at the time of the study, but from observations there are some students who need improvement in behavioral development with socially caring characteristics especially caring for their friends.

Table 3. Results of analysis of environmental care

\begin{tabular}{|c|l|c|c|}
\hline Num & \multicolumn{1}{|c|}{ Aspects observed } & Cycle I & Cycle II \\
\hline 1 & $\begin{array}{l}\text { Students do not agree } \\
\text { with the use of } \\
\text { chemicals that pollute } \\
\text { the environment }\end{array}$ & $88 \%$ & $92 \%$ \\
\hline 2 & $\begin{array}{l}\text { Students are concerned } \\
\text { about human actions } \\
\text { that damage the } \\
\text { environment }\end{array}$ & $84 \%$ & $88 \%$ \\
\hline 3 & $\begin{array}{l}\text { Students do not like the } \\
\text { dirty learning }\end{array}$ & $76 \%$ & $80 \%$ \\
\hline
\end{tabular}




\begin{tabular}{|c|c|c|c|}
\hline Num & Aspects observed & Cycle I & Cycle II \\
\hline & environment & & \\
\hline 4 & $\begin{array}{l}\text { Students use tools } \\
\text { according to } \\
\text { instructions and } \\
\text { maintain laboratory } \\
\text { cleanliness }\end{array}$ & $76 \%$ & $72 \%$ \\
\hline 5 & $\begin{array}{l}\text { Students like the cool } \\
\text { and beautiful place }\end{array}$ & $76 \%$ & $92 \%$ \\
\hline
\end{tabular}

Based on Table 3 it can be seen that the activities of students in the character of environmental care in the first cycle developed towards a better direction in the second cycle. It can be seen that more students carry out environmental care activities based on indicators of environmental awareness at the time of the study. But from the observations there are some students who need improvement in the development of behavioral characteristics that care about the environment, especially the environmentally caring behavior towards maintaining class cleanliness.

Table 4. Results of analysis of student responsibility

\begin{tabular}{|c|l|c|c|}
\hline Num & \multicolumn{1}{|c|}{ Aspects observed } & Cycle I & Cycle II \\
\hline 1 & $\begin{array}{l}\text { Students work on } \\
\text { assignments according } \\
\text { to orders and need to } \\
\text { be done. }\end{array}$ & $80 \%$ & $76 \%$ \\
\hline 2 & $\begin{array}{l}\text { Students can be trusted } \\
\text { in carrying out } \\
\text { activities. }\end{array}$ & $78 \%$ & $84 \%$ \\
\hline 3 & $\begin{array}{l}\text { Students do not blame } \\
\text { others, if they make } \\
\text { mistakes for } \\
\text { themselves. }\end{array}$ & $78 \%$ & $88 \%$ \\
\hline 4 & $\begin{array}{l}\text { Students carry out } \\
\text { their commitments }\end{array}$ & $68 \%$ & $76 \%$ \\
\hline
\end{tabular}

Based on Table 4. it can be seen that student activities on the character of responsibility in the first cycle meeting experienced development and the attitude of student responsibility began to look good in the second cycle. It can be seen that more students carry out responsible character activities based on indicators of responsibility at the time of research, but from observations there are some students who need improvement in developing responsible character behavior, especially in the responsibility of working on tasks in groups and presentations.

Table 5. The results of the analysis of the attitude of cooperation

\begin{tabular}{|c|l|c|c|}
\hline Num & \multicolumn{1}{|c|}{ Aspects observed } & Cycle I & Cycle II \\
\hline 1 & $\begin{array}{l}\text { Students work on } \\
\text { practical tasks and } \\
\text { groups together }\end{array}$ & $64 \%$ & $76 \%$ \\
\hline 2 & $\begin{array}{l}\text { Students are happy } \\
\text { when invited to } \\
\text { discuss friends and } \\
\text { solve problems } \\
\text { together. }\end{array}$ & $80 \%$ & $88 \%$ \\
\hline
\end{tabular}




\begin{tabular}{|c|l|c|c|}
\hline Num & \multicolumn{1}{|c|}{ Aspects observed } & Cycle I & Cycle II \\
\hline 3 & $\begin{array}{l}\text { Students are } \\
\text { accustomed to solving } \\
\text { problems together. }\end{array}$ & $66 \%$ & $76 \%$ \\
\hline 4 & $\begin{array}{l}\text { Students are not } \\
\text { individualistic }\end{array}$ & $66 \%$ & $88 \%$ \\
\hline
\end{tabular}

Based on Table 5 it can be seen that student activity on the character of cooperation shows progress towards a better direction, and the attitude of cooperation between students begins to be seen in completing group assignments. It can be seen that more students do activities based on indicators working together during the study. Students work on assignments given by the teacher in groups and have discussions with fellow friends, but from the results of observations there are some students who still need improvement in the development of behavior with the character of cooperation, especially in completing group assignments, because there are some students who are still working on assignments individually.

\section{Discuccion}

Based on the results of the research data on the learning activities that have been carried out, the results show that there are 1 student who is not completed with a score of 72 after being evaluated in cycle 2 (second cycle). That is because the student's readiness is still lacking. As for the evaluation of other students the average is good enough above the KKM. From the results of the observational analysis of learning feasibility in the first cycle obtained an implementation percentage of $94 \%$, if calculated on a scale of 1-100 according to the assessment matrix the value is 82 which is classified as good. The activity that was not carried out at the meeting was to submit a practicum procedure. This is because the utilization of time allocations made by teachers is still not good. From the results of observations of learning feasibility in the second cycle obtained an implementation percentage of $100 \%$, if calculated on a scale of 1-100 according to the assessment matrix the value is 90 which is classified as very good. This means that the teacher has conducted an evaluation of himself from the first cycle, and improved his learning activities in cycle II. For management of learning can be said in the cycle II the teacher has managed learning very well.

Based on the analysis of the data from the observations of the teacher on the character of students and the results of student responses in the form of a characteristic self-assessment questionnaire, in the learning cycle one was quite good. After going through the stages in the second cycle, there is a positive character development towards a better direction in students. Students are involved in learning activities and interact with each other in study groups and show the development of socially caring characters, caring for the environment, cooperation and responsibility. This shows that when students' character learning activities develop, there are still some students who need to be more intensive and need attention in developing their character. Therefore, to build positive character of students in each character training learning activities need to be trained continuously, so that their development will increase and become more entrenched in students.

\section{CONCLUSION}

Implementation of learning that is applied to train the character of students in the first cycle of implementation is $94 \%$ and its value according to the assessment rubric is 82 which is classified as good, after reflection by the teacher and continuing in second cycle, the learning implementation is $100 \%$ and the value in accordance with the assessment rubric is 90 very good. The results of training the character of students in the first cycle based on the results of teacher observation and self-assessment questionnaire character behavior has 
shown progress in students. After reflection by the teacher and continuing in cycle II, it can be seen that there is a development of positive characters in students towards a direction that is better than before, based on the results of the teacher's observation of character behavior.

\section{REFERENCES}

[1] Muhaimin, Akhmad. 2011. Urgency of Character Education in Indonesia. Yogyakarta: Ar-ruz media.

[2] Najib. 2010. Character Education. Surabaya: Jaring Pena.

[3] Akbar, S., Samawi, A., Arafik, M. \& Hidayak, L. 2015. Character Education: Best Practices. Malang: Malang State University.

[4] Abdullah, B., Radiansyah, \& Akbar, A. 2015. Character Education in State Madrasah Aliyah (MAN) 2 Banjarmasin. Inference, Journal of Social Research Religion, 9 (2), $537-$ 560 .

[5] Nur. 2011. Cooperative Learning. Surabaya: UNESA Press.

[6] Riduwan. 2010. Measurement Variables of Research Variables. Bandung: Alfabeta.

[7] Samani, Muchlas. 2011. Character Education. Bandung: PT Remaja Rosdakarya. 